\title{
Resenha: Psicologia Escolar: Ética e Competências na Formação e Atuação Profissional
}

\author{
Zilda A. Pereira Del Prette \\ Universidade Federal de São Carlos

\section{Book Review: Educational Psychology: Ethics and Competences in Professional Education and Performance}

Para onde caminha a Psicologia Escolar? O que se pode aprender de sua história passada e recente? Quais as direções mais atuais para os psicólogos lidarem, de forma competente e comprometida, com as questões educacionais? Quais os avanços e impasses da formação teórico-epistemológica do psicólogo comprometido com tais questões? Quais as competências que deveriam ser garantidas na sua formação acadêmica e continuada, considerando-se a realidade brasileira e as tendências internacionais na área? Como se articula a dimensão ética às suas demais competências?

Essas são somente algumas das questões que permeiam o novo livro do Grupo de Trabalho em Psicologia Escolar que, na Associação Nacional de Pesquisa e Pós-Graduação em Psicologia (ANPEPP), vem, desde 1989, discutindo a realidade educacional brasileira e apresentando propostas para a formação e a atuação do psicólogo escolar.

Esta nova obra é composta por dez capítulos, organizados em quatro partes, complementares e articuladas entre si, com relação ao seu propósito geral de oferecer subsídios para a formação e atuação em Psicologia Escolar.

Na primeira parte - Formação inicial: Panorama histórico e questões atuais -composta por dois capítulos - os seus autores examinam as relações entre Psicologia e Educação no Brasil, desde a época colonial até a história mais recente, com pesquisas de levantamento com alunos e profissionais de Psicologia sobre as condições de preparação e de atuação do psicólogo, em particular, do psicólogo vinculado ao trabalho em escolas.

Na segunda parte - Formação continuada e exercício profissional: $O$ desenvolvimento de competências - os três capítulos exploram a questão das competências necessárias para lidar com as demandas que hoje se colocam à atuação do psicólogo (definidas em termos de saberes éticos e práticos, bem como de habilidades pessoais, interpessoais, éticas e estéticas), com propostas inovadoras de assessoria na capacitação continuada desse profissional, um modelo de avaliação e intervenção das queixas escolares e uma análise das possibilidades e desafios inerentes às diversas funções que o psicólogo pode assumir na escola.

A parte seguinte - Exercício profissional em foco: $O$ desafio da prática - aprofunda a análise da atual realidade sócio-cultural em seus desafios e demandas para a Educação de um modo geral e para o fazer do psicólogo em particular. O capítulo final deste bloco retoma a questão da identidade profissional a partir de dados empíricos coletados com psicólogos escolares e de expectativas dos professores, com discussão de questões pertinentes à congruência entre tais representações.

Na última parte - Para além de currículos e programas: O compromisso ético-político do psicólogo escolar - os dois capítulos fecham o livro com duas questões candentes na atuação de qualquer profissional, mas particularmente críticas, no caso daqueles comprometidos com a melhoria da Educação em nosso país: o seu papel político e o sentido ético de sua prática. O papel político do psicólogo escolar é objeto de reflexões que se embasam em tendências internacionais. A questão ética também é abordada a partir de uma análise filosófica e epistemológica, permitindo extrair diretrizes essenciais para a formação e a atuação do psicólogo escolar.

O livro Psicologia escolar: Ética e competências na formação e atuação profissional traz, em seu conjunto, contribuições indispensáveis para os profissionais responsáveis pela graduação, pós-graduação e formação continuada dos psicólogos que atuam na área educacional. A obra revela a produtividade de um grupo que vem regularmente atualizando a análise de questões e apontando direções para uma Psicologia comprometida e competente no campo da Educação.

\section{Referência}

Almeida, S.F.C. de (Org.) (2003). Psicologia escolar: Ética e competências na formação e atuação profissional. Campinas: Alínea.

1 Endereço: Departamento de Psicologia da Universidade Federal de São Carlos. Via Washington Luiz, km 235 - Caixa Postal 676. 13560000 São Carlos, SP, Brasil. E-mail: zdprette@ power.ufscar.br - http:

//www.rihs.ufscar.br 


\section{Mudanças nas exigências para a preparação de manuscritos}

Mudanças nas exigências para a preparação de manuscritos podem inicialmente ser inconvenientes e frustrantes para os autores que submetem seus trabalhos. (APA, 1994, p. xxx)

No caso de Psicologia: Teoria e Pesquisa, os padrões adotados são baseados nas Normas da American Psychological Association [APA]. Novas exigências têm sido introduzidas, acompanhando as atualizações do estilo APA (como foi o caso da $4^{\text {a }}$ edição do Manual de Publicação, publicado em 1994). Em 1995, também houve mudanças devidas aos procedimentos operacionais e à tecnologia de produção, com a atualização dos procedimentos de editoração eletrônica e o novo formato da revista.

As exigências de formatação visam facilitar as tarefas de exame dos manuscritos e de produção dos artigos. Estabelecem limites convencionais na publicação científica - praticamente não trazem novidades; são apenas explicitações e detalhamentos que orientam os autores no cumprimento de exigências antigas.

As notas de Orientação aos Autores, publicadas regularmente desde o Volume 10, trazem lembretes de exigências típicas da publicação, dando destaque às providências mais comuns no fluxo de tramitação de manuscritos. Tais lembretes referem-se a orientações encontradas em todos os textos de orientação para a publicação científica - p. ex., sobre a qualidade da redação, e a organização do relato.

Para atendimento das normas em vigor, os autores devem basear-se nas instruções publicadas no número mais recente da Revista.

Para obter orientação mais detalhada, os autores devem consultar o Manual de Publicação da APA (1994, $4^{\text {a }}$ ed.).

O Editor pode ser consultado, caso persistam dúvidas.

Convidamos os autores interessados a escreverem para Psicologia: Teoria e Pesquisa solicitando informações, apresentando suas críticas e sugestões. 